\title{
Escritores tradutores brasileiros e a tradução dos nomes próprios
}

\author{
Germana DE SOUSA ${ }^{1}$ \\ Sonia PUTTINI \\ Camilla MARIATH \\ Aline BISPO \\ J akeline NUNES
}

Universidade de Brasília (UnB)

Brasil

Resumo: Trata-se de verificar como se dá a tradução de nomes próprios na prosa traduzida para o português do Brasil por grandes escritores brasileiros no âmbito da Editora e Livraria do Globo de Porto Alegre. As obras do corpus são constituídas por romances e contos pertencentes ao cânone da literatura em língua inglesa e da literatura francesa.

Palavras-chave: literatura traduzida versus literatura nacional, tradução de nomes próprios, história da tradução no Brasil.

\begin{abstract}
This paper aims at investigating the translation of proper names, anthroponyms, toponyms, in classical narratives translated into Brazilian Portuguese by major Brazilian writers and published by Globo Publisher and Bookstore of Porto Alegre (Editora e Livraria do Globo de Porto Alegre). The corpus is composed of canonical narratives from French, English and North American literatures.
\end{abstract}

Keywords: literature translated versus national literature, translation of proper names, history of translation in Brazil.

\section{Em busca da história da tradução no Brasil}

Este artigo mostra resultados de uma pesquisa acerca das relações entre tradução e sistema literário, cujo objetivo maior é estudar a história da tradução no Brasil, sobretudo a tradução dos clássicos realizada pelos escritores/tradutores brasileiros. Segundo Even-Zohar (1999), a tradução pode ocupar uma posição primária no sistema literário do país receptor quando a literatura é i) jovem; ii) está em processo de formação ou iii) quando existem momentos de inflexão no sistema. No caso do Brasil, a

1 Profa. Dra. Germana Henriques Pereira de Sousa, Departamento de Línguas estrangeiras e tradução. As coautoras deste artigo são estudantes-pesquisadoras do bacharelado em LetrasTradução da UnB. 
literatura foi formada a partir da literatura europeia, segundo a dialética do local/cosmopolita (Candido 1958). Em seu processo formativo, a literatura brasileira recebeu as influências dos movimentos estéticos europeus, veiculadas, em parte, pelas traduções. A tradução ocupou, e talvez ainda o faça, uma posição primária na formação do sistema literário brasileiro. Isto se vê tanto na relação que os escritores brasileiros mantêm com a tradução, sendo a grande maioria deles tradutores, quanto no modo como o Brasil traduziu os clássicos da literatura universal.

Os objetivos são, portanto, i) investigar a relação entre a literatura nacional e a literatura traduzida por meio do estudo das traduções realizadas pelos escritores/tradutores brasileiros; ii) analisar criticamente a tradução dos clássicos e suas retraduções por meio do estudo dos textos de acompanhamento (capas, títulos, prefácios, posfácios, notas e glossários), e da análise crítica da obra traduzida (estilo, pontuação, léxico, transferências culturais).

A metodologia empregada para a análise dos textos de acompanhamento fundamenta-se naquela desenvolvida por RisterucciRoudnicki (2007) que encara a obra traduzida como um híbrido cultural. As noções de sistema literário, como histórico e dinâmico, aqui empregadas, partem dos estudos de Candido $(1958 ; 2000)$ sobre o processo formativo brasileiro, e de Itamar Even-Zohar (1999), que desenvolveu a teoria dos polissistemas, cujos objetivos remetem ao estudo da tradução como veículo portador das vogas estéticas e dos gêneros literários de uma comunidade cultural a outra. Gideon Toury (1995), também polissistemista, foca sua análise do fenômeno da tradução na cultura de chegada, ou seja, no polo receptor, uma vez que este determina o quê e como traduzir; para isso, Toury investiga as normas de tradução. O método crítico de Antoine Berman (1995), que leva em conta o estatuto do tradutor e sua ética, é igualmente considerado para a análise dos escritores/tradutores brasileiros. A relação entre a literatura e suas margens, o discurso da crítica e a manipulação da literatura por meio da tradução, serão estudados do ponto de vista ideológico segundo os trabalhos de André Lefevere (2007).

O objetivo principal deste projeto é realizar um mapeamento das traduções realizadas no Brasil à época de ouro das traduções, também conhecida como a época do "boom" das traduções, sobretudo daquelas editadas e realizadas pela equipe de tradutores da Livraria e Editora do Globo de Porto Alegre, e pela José Olympio, que eram também, e não por coincidência, grandes escritores brasileiros. Essa cartografia, ainda que parcial, haja vista a amplitude do corpus, será realizada até 2013, quando será publicada em forma de livro.

Para este artigo, cujo tema é a tradução dos nomes próprios, declinados em antropônimos (nome, sobrenome, hipocorístico) de indivíduos reais ou fictícios, topônimos (lugares, monumentos), e demais 
2. The practice, didactics and critiques of translation / Pratique, didactique et critique de la traduction / Praxis und Didaktik des Übersetzens, Übersetzungskritik / Pratica, didattica e critica della traduzione / Práctica, didáctica y crítica de la traducción/

referentes culturais, o corpus de análise será a pesquisa em curso de realização e elaborada pelas coautoras deste artigo, sob minha orientação: $A$ época de ouro das traduções no Brasil: o caso da Editora do Globo de Porto Alegre. O projeto de pesquisa (PROIC 2010-2011/CNPq/UnB) desdobra-se em quatro trabalhos individuais: a) Aline Bispo Lopes Magalhães - Erico Verissimo tradutor de Katherine Mansfield; b) Camilla de Miranda Mariath Gomes - Carlos Drummond de Andrade tradutor de Balzac; c) Jakeline Pereira Nunes - Cecília Meireles tradutora de Virgínia Woolf; d) Sonia Maria Puttini - Mário Quintana tradutor de Proust. Os textos analisados são respectivamente: a) Bliss; b) Les paysans; c) Orlando - a Biography; d) Du côté de chez Swann.

Antes de passarmos à análise, vale ressaltar o contexto histórico e cultural brasileiro no qual se inserem os trabalhos dos autores/tradutores citados.

No Brasil dos anos 30 e 40 (Sousa 2009), as editoras José Olympio e Globo tiveram importante papel na divulgação e difusão de obras literárias, dos clássicos à literatura para jovens, aos romances policial e de ficção científica. Segundo John Milton (2002), os anos 30 foram a década de ouro da tradução, graças ao incentivo do governo Vargas, que criou o Instituto Nacional do Livro e várias bibliotecas. Vale ressaltar o sucesso absoluto da criação de coleções de obras traduzidas, como a coleção Nobel. Grandes escritores tornaram-se tradutores empregados pela editora Globo, que desse modo lhes proporcionava uma nova fonte de renda. O papel dessas publicações era popularizar a leitura dos clássicos universais, o acesso à leitura de públicos não especialistas e a grande circulação de obras, por exemplo, a tradução de Proust por Mário Quintana foi um dos best-sellers da Editora Globo, com 66 mil exemplares publicados. Visava também formar um público leitor, disseminar a cultura estrangeira, alçar os leitores brasileiros ao patamar internacional de modo a que se sentissem parte de um conjunto cultural mais amplo: o dos leitores das letras clássicas universais. Era igualmente uma forma de disseminar as grandes obras da literatura nacional, que eram publicadas em coleções conjuntas com as obras estrangeiras, um modo de legitimar as obras nacionais. Milton ressalta ainda a importância do Clube do Livro (Milton 2002), que fazia o que ele chama de "tradução de fábrica", em oposição à "tradução artesanal", promovida pelas grandes editoras.

A partir de 1930, a Livraria Globo ganha caráter de editora graças ao sucesso alcançado por Henrique Bertaso ao decidir criar uma seção editorial dentro da livraria. Tendo como foco as traduções de obras francesas, inglesas e norte-americanas, a Livraria e Editora do Globo de Porto Alegre foi de fundamental importância para a divulgação no Brasil do cânone universal. Na organização deste ramo editorial, Bertaso conta com a participação de Erico Verissimo, que auxiliou tanto na organização deste 
novo empreendimento, quanto nas escolhas dos livros a serem traduzidos. Quando decidia quais obras seriam editadas pela Globo, Erico Verissimo priorizava aquelas mais densas e cultas no intuito de valorizar a literatura e enriquecer o conhecimento do leitor.

\section{A tradução dos nomes próprios}

Segundo Martinet (1982), no texto literário, os nomes próprios não desempenham uma simples função denotativa de seres e lugares. Nesse sentido, esses nomes desempenham uma função mais ampla, que exige do tradutor uma análise do texto em sua totalidade para alcançar uma compreensão do que representam no universo ficcional da obra. A partir dessa análise aprofundada, podemos pensar em algumas posições para o tradutor em relação aos nomes próprios: i) podem ser conservados como aparecem no texto original, ii) podem ser traduzidos por equivalentes conotativos da língua de chegada e iii) podem ser adaptados foneticamente, principalmente no caso de textos poéticos e dramáticos.

A compreensão dos papéis que os nomes próprios desempenham numa narrativa, assim como o lugar que eles ocupam no universo literário do autor, é condição necessária para absorvermos a essência do texto e sua totalidade. Berman explica que "todo texto a ser traduzido apresenta uma sistematicidade própria que o movimento de tradução encontra, enfrenta e revela”. (Berman 2002, 20) A presença de nomes próprios dá forma a essa sistematicidade e, portanto, exige que ela seja decifrada pelo leitor e pelo tradutor.

\section{II.1. Bliss ou Felicidade}

Entre os autores traduzidos por Verissimo encontramos Agatha Christie, Somerset Maugham e Katherine Mansfield. Alguns de seus trabalhos foram assinados com o pseudônimo "Gilberto Miranda". Para a pesquisa é proposta a análise das traduções feitas por Erico Verissimo dos contos Psychology, Bliss e Her First Ball, de Katherine Mansfield, publicados pela Editora Globo, em 1939 e 1940. Para a análise dos nomes próprios que concerne este artigo, será estudado o caso do conto Bliss.

Katherine Mansfield nasceu em 1888, na Nova Zelândia e morreu em 1923, aos 34 anos. Dentre os diversos contos escritos por ela, Bliss é um dos mais famosos e foi publicado em diversas coletâneas da obra da autora. No Brasil, este conto foi traduzido pela primeira vez em 1940 por Erico Verissimo e publicado pela Editora e Livraria do Globo de Porto Alegre. Os direitos da publicação foram comprados pela Editora Nova Fronteira, na tradução de Verissimo. Nos anos 1990, a Editora Revan publicou uma coletânea de contos de Mansfield intitulada Felicidade e outros contos, 
2. The practice, didactics and critiques of translation / Pratique, didactique et critique de la traduction / Praxis und Didaktik des Übersetzens, Übersetzungskritik / Pratica, didattica e critica della traduzione / Práctica, didáctica y crítica de la traducción/

traduzida por Julieta Cupertino². Apesar de manter o mesmo título, a publicação da Revan difere de ambas as anteriores que apresentam traduções de Verissimo.

A análise do conto partirá das traduções citadas acima e o principal motivo para a escolha de Bliss é que, já a partir do título, encontramos dificuldade e peculiaridade na tradução, pois:

Tal como "saudade" em português, "bliss" é uma palavra inglesa sem correspondente exato em outras línguas. Êxtase, felicidade total, euforia, há muitas traduções possíveis, mas nenhuma atende a todas as nuances da palavra original. (Cupertino apud Gonçalves 2008)

Todavia, Cupertino, na esteira de Verissimo, traduz Bliss por Felicidade. A situação cênica descrita em Bliss ocorre na casa da protagonista, Bertha Young. Esta recebe alguns amigos para jantar, e, portanto, a maioria dos substantivos próprios do texto refere-se aos nomes das personagens. Em alguns casos fica flagrante a relação entre a personagem e seu nome. Este é o caso de Pearl Fulton, uma personagem admirada e querida pela protagonista da história. Em inglês "pear" quer dizer "pera" ; ao nome da personagem Pearl é acrescido apenas o "l" para diferenciar o nome próprio daquele da fruta. Entretanto há uma forte ligação entre a protagonista Bertha, uma pereira (a árvore) e a personagem Pearl Fulton. Há um pé de pera lindo e florido no quintal de Bertha Young e esta árvore é citada no conto diversas vezes pela sua beleza, assim como Pearl Fulton é admirada e citada diversas vezes pela protagonista. Ao escolher "Pearl" como prenome da personagem admirada por Bertha, Mansfield parece pretender adjetivar a personagem com as mesmas qualidades da árvore e, t-ambém, fazer entender que a admiração da protagonista pela árvore e pela mulher era a mesma. Entretanto, nas traduções analisadas, ambos os tradutores optaram por não traduzir o nome, deixando o leitor fazer por si próprio a aproximação. Por outro lado, "Pearl" em inglês significa pérola, nome que tampouco é usado nas traduções e cuja simbologia remete à delicadeza, à pureza. Dois outros

2 Coletânea de Verissimo: Bliss (Felicidade); Mr. Reginald Peacock's Day (O dia de Mr. Reginald Peacock); The Escape (A evasão); Taking the veil (Nuvem de Primavera); Psychology (Psicologia); Je ne parle pas français (Je ne parle pas français); Feuille D'album (Feuille D'album); The little governess (A jovem governanta); Her first ball (O seu primeiro baile); The singing lesson (A lição de canto); The wind blows (O vento sopra); Sun and Moon (Sol e Lua); Revelations (Revelações) e Prelude (Prelúdio). Na coletânea de Cupertino: Bliss (Felicidade); Psychology (Psicologia); Mr. Reginald Peacock's Day (Um dia de Reginald Peacock); The little governess (A pequena governanta); The daughters of the late colonel (As filhas do falecido coronel); Mariage à la mode (Marriage à la mode); Something childish but very natural (Um tanto infantil, mas muito natural) e The canary (O canário). 
nomes de personagens que aparecem no texto e podem exprimir qualidade são Face e Mug. Estes são apelidos dados ao casal de amigos que Bertha convida; no conto fica claro que eles só se chamam assim quando estão entre pessoas íntimas. Os tradutores mantiveram os nomes do original em inglês, mas tanto "mug" quanto "face" podem ser traduzidos por "careta", o que transmitiria ao leitor um pouco mais da excentricidade das personagens.

Dos nomes próprios encontrados no conto, Erico Verissimo traduziu aqueles que, em português, são bastante comuns; é o caso de "Mary" que ficou "Maria" e "Jacob" adaptado para "Jacó". Verissimo também adaptou à grafia do português o nome de "Bertha" ("Berta"); já o nome do bebê "Little B" foi traduzido para "pequena B". Os demais nomes foram mantidos como no original, inclusive o substantivo próprio "nurse", comumente designador da profissão de enfermeira, e que no conto remete à função de babá, não foi traduzido. A enfermeira também é chamada por Bertha de "Nanny", que é babá em português, mas o nome tampouco foi traduzido, o que mostra certa incongruência por parte das escolhas tradutórias.

Julieta Cupertino optou por manter praticamente todos os nomes das personagens como no original, com exceção de "Little B" que foi traduzido por "pequena B". Para "nurse", ou "Nanny", a tradutora optou por "babá", como é mais comum no Brasil.

Tradução dos os nomes das personagens

\begin{tabular}{|l|l|l|}
\hline Original & Erico Verissimo & Julieta Cupertino \\
\hline Bertha Young & Berta Young & Bertha Young \\
\hline Mary & Maria & Mary \\
\hline Little B & pequena B. & pequena B. \\
\hline Nanny & Nanny & Nanny \\
\hline Harry & Harry & Harry \\
\hline Norman Knight & Norman Knight & Norman Knight \\
\hline Eddie Warren & Eddie Warren & Eddie Warren \\
\hline Pearl Fulton & Pearl Fulton & Pearl Fulton \\
\hline Face & Face & Face \\
\hline Mug & Mug & Mug \\
\hline Jacob Nathan & Jacó Nathan & Jacob Nathan \\
\hline Bilks & Bilks & Bilke \\
\hline
\end{tabular}


2. The practice, didactics and critiques of translation / Pratique, didactique et critique de la traduction / Praxis und Didaktik des Übersetzens, Übersetzungskritik / Pratica, didattica e critica della traduzione / Práctica, didáctica y crítica de la traducción/

Além dos nomes das personagens, há também no texto a alusão a três títulos de peças teatrais, até onde sabemos, ficcionais: um remete a uma expressão em francês e os outros dois estão em inglês. Na tradução de Verissimo, Table d'Hôte, expressão francesa que significa "refeição servida a preço prefixado incluindo entrada, prato principal e sobremesa”, passa a ser "Table d'Hôtel”, uma adaptação na própria língua francesa e que mantém o estranhamento em português do Brasil. Já o título Stomach trouble é vertido como "Perturbações digestivas". A última peça citada em Bliss, Love in false Teeth, foi traduzida como "Amor com dentes postiços". Nos dois últimos casos há uma tentativa de naturalização por parte de Verissimo, com conservação do humor presente nos títulos originais. No primeiro título em francês, a adaptação, ou tentativa de, não faz muito sentido e resulta numa exotização.

Cupertino traduziu "Table d'Hôte" por "Mesa de Convidado", que não remete em português do Brasil ao mesmo significado em francês; deixou Love in false Teeth como no original, optando por uma nota de rodapé para esclarecer que se tratava da obra "Amor em dentes postiços". Stomach trouble foi traduzido por "Dor de estômago", mais adequado e mais simples do que "Perturbações digestivas", de Verissimo. Ainda no texto de Cupertino, o nome próprio "Michael Oat" aparece como "Michael Ost", provavelmente um engano, já que é possível que a substituição da letra "a" pelo "s" tenha passado desapercebida pela editora. Cupertino faz a adaptação do sobrenome do escritor russo Tchekov, que Verissimo não faz.

Tradução dos títulos das peças teatrais e nomes de autores

\begin{tabular}{|l|l|l|}
\hline Original & Erico Verissimo & Julieta Cupertino \\
\hline Michael Oat & Michael Oat & $\begin{array}{l}\text { Michael Ost (possível erro } \\
\text { editorial) }\end{array}$ \\
\hline Love in false Teeth & $\begin{array}{l}\text { Amor com dentes } \\
\text { postiços }\end{array}$ & $\begin{array}{l}\text { Love in false Teeth (com } \\
\text { nota de rodapé: Amor em } \\
\text { dentes postiços) }\end{array}$ \\
\hline Stomach trouble & Perturbações Digestivas & Dor de estômago \\
\hline Tchekof & Tchekof & Tchekov \\
\hline Table d'Hôte & Table d'Hôtel & Mesa de Convidado \\
\hline
\end{tabular}

Com relação à tradução dos topônimos, em ambas as traduções, o nome da capital inglesa London foi traduzido pelo equivalente em português, "Londres", mas o bairro londrino Hampstead não recebeu tradução. 
Concluímos daí que há uma hesitação evidente na tradução de nomes próprios e títulos de obras citadas, porém a tradução de Cupertino, mais recente, tende a traduzir menos.

\section{II.2. Les Paysans ou Os Camponeses}

A obra A Comédia Humana (La Comédie Humaine), de Honoré de Balzac, foi publicada pela primeira vez no Brasil no ano de 1954. Com orientação, introdução e notas do escritor e tradutor Paulo Rónai, a edição brasileira conta com dezessete volumes, divididos em Estudos de Costumes (Cenas da Vida Privada, Cenas da Vida Provinciana, Cenas da Vida Parisiense, Cenas da Vida Política, Cenas da Vida Militar e Cenas da Vida Rural), Estudos Filosóficos e Estudos Analíticos.

Dentre as obras mais conhecidas de A Comédia Humana, estão $A$ Mulher de Trinta Anos, Ilusões Perdidas, Eugênia Grandet, Úrsula Mirouët, O Pai Goriot, entre outras. Nelas, Balzac serviu-se de seu talento inegável para a escrita e propôs a criação de um gênero literário presente até hoje na literatura mundial, o romance burguês, baseando-se em estudos e pesquisas sobre a sociedade em que viveu (Rónai 1947, 14), a qual passava por um momento de grandes transformações, influenciada pelo processo de surgimento do capitalismo e da burguesia francesa. Estes são temas recorrentes em seus livros, mas não os únicos.

Analisaremos neste artigo a tradução de Les Paysans (Os Camponeses) feita pelo grande poeta brasileiro, Carlos Drummond de Andrade, em 1954. Obra póstuma de Balzac, publicada em 1855 e deixada inacabada em 1844, Les Paysans retrata o conflito entre os grandes proprietários de terras e os proletários do campo. O objetivo é analisar as escolhas feitas por Drummond, sob a cautelosa supervisão de Paulo Rónai, quanto à tradução de nomes próprios contidos na obra. Para essa finalidade, será necessário dividir esses nomes em três macroestruturas: personagens da narrativa, personagens históricas e topônimos.

Jacques Derrida (2002 apud Esqueda 2004, 163), a propósito da tradução de um nome próprio, afirma que este:

enquanto tal, permanece sempre intraduzível, fato a partir do qual pode-se considerar que ele não pertence, rigorosamente, da mesma maneira que as outras palavras, à língua, ao sistema da língua.

É importante observar a princípio que a compilação balzaquiana de oitenta e nove romances e novelas foi idealizada para ser uma única obra, por essa razão, é rica em intertextualidades: personagens que aparecem e 
2. The practice, didactics and critiques of translation / Pratique, didactique et critique de la traduction / Praxis und Didaktik des Übersetzens, Übersetzungskritik / Pratica, didattica e critica della traduzione / Práctica, didáctica y crítica de la traducción/

reaparecem e que são citadas em diferentes volumes de $A$ Comédia Humana (Rónai 1947, 15).

Tradução dos nomes das personagens da narrativa

\begin{tabular}{|l|l|}
\hline Original & Drummond \\
\hline Émile Blondet & Emílio Blondet \\
\hline Montcornet & Montcornet \\
\hline Nathan & Nathan \\
\hline Florine & Florina \\
\hline Mariette & Marieta \\
\hline Suzanne du Val-Noble & Susana do Val-Nobre \\
\hline l'abbé Brossette & Padre Brossette \\
\hline madame de Moncornet & Condessa de Moncornet \\
\hline père Fourchon & tio Fourchon \\
\hline Mouche & Mosquito \\
\hline Charles & Carlos \\
\hline Joseph & José \\
\hline
\end{tabular}

Alguns nomes dentre os listados acima foram apenas citados ao longo do livro, como Nathan, Florina, Marieta, Susana do Val-Nobre, outros, porém, como Blondet e Montcornet, apesar de também estarem presentes em outras obras, fazem parte do escopo de personagens centrais de Os Camponeses. Cabe ressaltar, portanto, que a tradução de nomes de personagens que já haviam aparecido em obras anteriores não ficou a cargo de Drummond, mas sim dos respectivos tradutores das obras - quatorze, no total. Não podemos esquecer que o prefaciador, anotador e organizador da edição brasileira, Paulo Rónai, foi o responsável pela revisão de todas as obras, nunca deixando de rever e corrigir os dezessete volumes, para que $A$ Comédia Humana fosse o mais fiel possível ao original, como ele mesmo pretendia:

Durante os anos que durou o preparo da edição brasileira da Comédia, Rónai tentou retratar o mais fiel e sistematicamente possível em português, o que Balzac queria dizer à sociedade francesa. (Esqueda 2004, 90) 
Podemos conferir, no texto drummondiano, diferentes escolhas na tradução de nomes próprios. Há a intenção de se deixar o nome da personagem afrancesado, mas com a tradução da função, como em padre Brossette, e da fórmula de tratamento, em Condessa de Moncornet. Podemos observar, no entanto, que Drummond optou por denominar Madame de Moncornet como Condessa de Montcornet, sendo a correspondência direta de "Madame", em português, a forma de tratamento Senhora. Ainda, no caso de Père Fourchon, supomos que Drummond adaptou o modo popular francês de se referir a um homem de certa idade, como "Père", em vez de "Monsieur", para "tio", fórmula também popular de tratamento no Brasil e que não remete a nenhuma relação de parentesco.

Drummond optou, ainda, por alterar o apelido "Mouche", cujo equivalente seria "mosca" em português, para "Mosquito", provavelmente por este remeter melhor à imagem de um garoto de cerca de doze anos. Os prenomes Joseph e Charles, traduzidos como José e Carlos, explicitam uma tendência naturalizadora que pode ser observada na obra como um todo: traduzir os prenomes das personagens, deixando os nomes de família com suas grafias francesas.

Esqueda (2004) comenta a inevitável escolha de Paulo Rónai em recorrer a notas de rodapé - em toda a Comédia, 7.493 - para, além de outros motivos, esclarecer ou explicar os trocadilhos que o autor francês realiza com relação aos nomes das personagens:

O nome próprio é a marca identificatória, mas também a marca do ofensivo, do sarcasmo. O que é mais próprio se torna o mais comum. $\mathrm{O}$ nome próprio desvela uma face, abre uma máscara social que pode ter também uma outra face, cuja máscara pode estar na língua, essa que não pertence. (Esqueda 2004, 113)

Há, no entanto, a escolha por parte de Drummond de traduzir os nomes das personagens históricas para as quais existe correspondência na língua portuguesa:

\begin{tabular}{|l|l|}
\hline \multicolumn{2}{|c|}{ PERSONAGENS HISTÓRICAS } \\
\hline ORIGINAL & DRUMMOND \\
\hline Napoléon & Napoleão \\
\hline Louis XVI & Luís XVI \\
\hline Henri IV & Henrique IV \\
\hline le Grand Dauphin & o Grande Delfim \\
\hline Breughel-de-Velours & Breughel-de-Veludo \\
\hline
\end{tabular}


2. The practice, didactics and critiques of translation / Pratique, didactique et critique de la traduction / Praxis und Didaktik des Übersetzens, Übersetzungskritik / Pratica, didattica e critica della traduzione / Práctica, didáctica y crítica de la traducción/

Entre os nomes apresentados acima, mencionamos reis e imperadores franceses, além de um pintor flamengo, Breughel. Para esse último, deixou-se o primeiro nome em língua estrangeira, mas traduziu-se Velours. Era costume no Brasil traduzir-se o nome de personagens históricas, a exemplo dos membros da realeza. Esse costume, no entanto, não é mais assaz observado nas traduções contemporâneas, talvez impulsionadas agora pela aproximação de culturas proporcionada pela globalização.

Existem, ainda, exemplos de nomes de lugares que não são traduzidos, tendo sido vertida apenas a indicação geográfica.

\begin{tabular}{|l|l|}
\hline \multicolumn{2}{|c|}{ Topônimos } \\
\hline Original & Drummond \\
\hline vallée des Aigues & vale das Aigues \\
\hline village de Couches & aldeia de Couches \\
\hline village de Blangy & aldeia de Blangy \\
\hline Sous-préfecture de La-Ville-aux-Fayes & Subprefeitura de La-Ville-aux-Fayes \\
\hline Palais de Versailles & Palácio de Versalhes \\
\hline Bourgogne & Borgonha \\
\hline La Seine & O Sena \\
\hline Suisse & Suíça \\
\hline Espagne & Espanha \\
\hline
\end{tabular}

Os topônimos, localidades ou monumentos cujos nomes existem como referentes na língua portuguesa, como os países Suíça e Espanha, foram vertidos normalmente, assim como a região da Borgonha, o rio Sena e o Palácio de Versalhes. Quanto aos nomes referentes especificamente ao território francês, isto é, desconhecidos da população brasileira, por exemplo, vale das Aigues, aldeia de Couches, aldeia de Blangy e subprefeitura de La-Ville-aux-Fayes, são traduzidas apenas as suas indicações geográficas (vale, aldeia, etc.) ou função (subprefeitura), seus nomes permanecendo em francês.

Para a análise da tradução dos nomes próprios presentes na obra $O s$ Camponeses, realizada por Carlos Drummond de Andrade para a Editora e Livraria do Globo de Porto Alegre, façamos uma reflexão, ainda que breve, acerca do par dicotômico fidelidade e traição, segundo Berman (2002). A questão de servir à obra do autor estrangeiro ou servir a sua própria língua 
é pertinente à análise da presente tradução, pois define a posição tradutória a que se propõe o tradutor, levando-o a tomar decisões, como deixar o texto mais fluente para o leitor brasileiro ou permitir uma margem de estrangeiridade à tradução pela conservação dos nomes próprios na língua estrangeira.

Seguindo essa lógica, podemos dizer que Carlos Drummond de Andrade, como afirma Costa (2002, § 15), é um tradutor que "recria a autoria estrangeira em sua língua". Sua posição tradutória, portanto, difere de sua posição como poeta, contista e cronista, na qual é sempre possível presenciarmos novas técnicas e temáticas (Costa, § 4). Segundo Paulo Rónai $(1987,100)$, Drummond é um dos tradutores "mais escrupulosos e mais fiéis" que conheceu.

Podemos concluir pela análise realizada neste artigo que o tradutor Carlos Drummond de Andrade, sob a meticulosa supervisão de Paulo Rónai, permite a entrada da atmosfera do original em sua tradução quando preserva a grafia francesa de alguns nomes próprios, garantindo, assim, a fidelidade mencionada - e tanto buscada - pelo estudioso da obra balzaquiana, Rónai. Ao mesmo tempo, porém, privilegia a leitura de seu público alvo, ao ambientar outros, trazendo um pouco da realidade da sociedade francesa retratada na coletânea de Balzac para o Brasil.

\section{II.3. Orlando entre Woolf e Cecília Meireles}

As obras da escritora inglesa Virginia Woolf, publicadas na primeira metade do século XX tornaram-se best-sellers e alcançaram tiragens impressionantes.. No romance Orlando - A Biography, publicado em 11 de outubro de 1928, ela tece uma homenagem a uma de suas amantes, Vita Sackville-West. A obra foi traduzida no Brasil por Cecília Meireles, escritora aclamada pela crítica nacional e tradutora renomada, tendo recebido o Prêmio de Tradução de Obras Teatrais (1962) e o Prêmio Jabuti de Tradução de Obra Literária pelo livro Poesia de Israel (1963)3. A poetisa traduziu a profundidade e a instabilidade psíquica da escritora inglesa, uma tarefa difícil que pode ter sido facilitada pela aproximação que podemos tecer entre a sensibilidade da poetisa brasileira e aquela da escritora londrina:

Esse modo de ser, de "ser Cecília", entre as inquietudes das declinações do eu e a serenidade utópica do indeclinável, é o que serve de suporte à construção do poema que se intitula explicitamente "Auto-retrato". "Se me contemplo,/ tantas me vejo,/ que não entendo/ quem sou, no tempo/do pensamento ("Auto-retrato", Mar Absoluto, p.271-3). (Hansen 2001)

3 Cf. http://www.dicionariodetradutores.ufsc.br/pt/CeciliaMeireles.htm 
2. The practice, didactics and critiques of translation / Pratique, didactique et critique de la traduction / Praxis und Didaktik des Übersetzens, Übersetzungskritik / Pratica, didattica e critica della traduzione / Práctica, didáctica y crítica de la traducción/

O prenome "Orlando", que intitula a obra biográfica mais famosa da autora, tem origem teutônica e significa "aquele que vem de país formoso". $\mathrm{O}$ título revela o desejo de homenagear àquela que foi um dos seus maiores amores, Vita, e também elucida a vontade de contar a História, assim como o fez o excêntrico marido de Vita West, o biógrafo Harold Nicolson. Quando o nome "Orlando" é separado, obtemos as sílabas Or- land- $o$; a sílaba do meio land significa "terra", que também pode ser, considerando-se o sentido, "território", "espaço”, "lugar”, como observado por Sandra Gilbert:

a public history of the private woman - as Orlando, returning at last from Turkey to reclaim her English inheritance, becomes England's figurative land-lady: the Lady Or-land-o, Ur-land-o, Her-land-o. (Gilbert 1992)

No livro, Woolf dá vida a Orlando, que tem sua história contada pelo "biógrafo" (presente em inúmeros trechos do livro). A jornada do jovem andrógino inglês se inicia no século XVI e atravessa diversos séculos da história inglesa. Ele tem diversas paixões avassaladoras e, após uma experiência mística na Pérsia, transforma-se em mulher. Nas traduções para o português, o título do livro é reduzido a Orlando, retirando-se o subtítulo "uma biografia".

Ao analisarmos de forma comparativa os nomes próprios presentes no original e suas traduções para o português, observamos que ora o nome é traduzido, caso dos topônimos e dos antropônimos de personalidades históricas, como reis, rainhas e escritores, ora é mantido como no original, como mostra o quadro abaixo.

Topônimos

\begin{tabular}{|l|l|}
\hline Original & Cecília Meireles \\
\hline London & Londres \\
\hline Africa & África \\
\hline France & França \\
\hline Turkey & Túrquia \\
\hline Harrogate & Harrogate \\
\hline British Museum & Museu Britânico \\
\hline Cheltenham & Cheltenham \\
\hline Record Office & Arquivo \\
\hline Bow Street & Bow Street \\
\hline
\end{tabular}


Assim, Africa, England e Turkey, são vertidos para África, Inglaterra e Turquia. Os topônimos que designam monumentos ingleses famosos, como o British Museum, foram adaptados. Entretanto, esse padrão nem sempre é seguido pela poetisa tradutora que manteve Bow Street em inglês e traduziu Record Office por Arquivo. Percebemos que a tradutora não se preocupou em criar um padrão, pois a versão dos antropônimos de personalidades históricas não foi adaptada, como nos casos de Queen Elizabeth I (Rainha Elizabeth), Charles II (Charles II).. Sacha, a primeira paixão avassaladora de Orlando, não tem o nome traduzido; o Capitan Nicholas Benedict Bartolus só tem o título de capitão traduzido. Os nomes dos barcos Marie Rose e Enamoured Lady comandados pelo Capitão Nicholas têm seus nomes mantidos, inclusive em itálico, como no texto fonte.

Os nomes de personagens da narrativa

\begin{tabular}{|l|l|}
\hline Original & Cecília Meireles \\
\hline Orlando & Orlando \\
\hline Sacha & Sacha \\
\hline Rosina Pepita & Rosina Pepita \\
\hline Sttubs & Sttubs \\
\hline Capitan Nicholas Benetict Bartolus & Capitão Nicholas Benetict Bartolus \\
\hline
\end{tabular}

No prefácio, Woolf agradece a diversos amigos, parentes e conhecidos. Na tradução, Cecília Meireles manteve os nomes próprios como no original, mas traduziu a fórmula de tratamento inglês Sir por "Sr.", abreviação de "Senhor" em português:

Antropônimos citados no Prefácio

\begin{tabular}{|l|l|}
\hline Original & Cecília Meireles \\
\hline Sir Thomas Browne & Sr. Thomas Browne \\
\hline Sterne & Sterne \\
\hline Vanessa Bell & Vanessa Bell \\
\hline Angelica Bell & Angelica Bell \\
\hline Mrs. M. K. Snowdon & Sra. M. K. Snowdon \\
\hline
\end{tabular}


2. The practice, didactics and critiques of translation / Pratique, didactique et critique de la traduction / Praxis und Didaktik des Übersetzens, Übersetzungskritik / Pratica, didattica e critica della traduzione / Práctica, didáctica y crítica de la traducción/

\section{II.4 No caminho de Swann}

A questão dos nomes próprios é marcante em toda a literatura de Marcel Proust por se remeter a conteúdos simbólicos que não estão simplesmente ligados ao mundo dos signos, mas que trazem em suas acepções mais profundas o poder de evocação de uma multiplicidade de sentidos. Na obra À la recherche du temps perdu (Em busca do tempo perdido), de Marcel Proust, o sentido do nomear parece dar forma à obra, constituindo, por vezes, o elo entre as trilhas desconhecidas que o narrador percorre e as memórias de uma trama psicológica e intrigante que se confunde com a realidade do autor.

No primeiro volume da obra, No caminho de Swann, esse aspecto está presente desde nosso primeiro contato com o livro. O título original, Du côté de chez Swann (Proust, 1913), remete-nos instantaneamente a um personagem, Charles Swann, que ao longo da narrativa se (con)funde com o caminho percorrido pelo narrador, que mais tarde será apresentado pelo autor-narrador. Este nos propicia, assim, um primeiro contato com a narrativa, apresentando a primeira ponta do fio que se desenrolará ao longo da trama. Logo após o título do livro, somos levados novamente a refletir sobre a questão dos nomes próprios por meio do título do primeiro capítulo. Somos apresentados a Combray, cidadezinha fictícia em que o narrador passa com os pais as férias de Páscoa e onde recebem a visita de Swann. Esse aspecto permeia toda a narrativa, desembocando no último capítulo intitulado Nomes de terras: o nome, em que o autor descreve a importância dos nomes em sua trajetória conferidos às cidades de sua imaginação. Além dos exemplos citados acima, seguem-se muitos outros nomes e traços que representam essa importante reflexão na obra de Proust.

Tendo como ponto de partida o lugar de destaque da questão de nomes próprios oferecido por Proust (1913) em Du côté de chez Swann, será analisado como essa questão se faz presente na tradução do renomado escritor e tradutor Mário Quintana (1948), intitulada por ele No Caminho de Swann, publicada pela Editora e Livraria do Globo, e na tradução de Fernando Py, publicada pela Ediouro. Portanto, a título de comparação, as tabelas que se seguem contêm tanto os nomes próprios encontrados na tradução de Mário Quintana (1948), como os encontrados na tradução de Fernando Py (2004).

Na tradução de $D u$ côté de chez Swann (Proust, 1913), Mário Quintana (1948) e Fernando Py (2004) mantiveram em seus textos uma grande parte dos nomes próprios como no original. Em relação às personagens da narrativa, observamos que os nomes e sobrenomes foram todos mantidos como na língua de partida nas duas traduções, como mostra o quadro abaixo. 


\begin{tabular}{|c|c|c|}
\hline \multicolumn{3}{|c|}{ Personagens da narrativa } \\
\hline Original & Mário Quintana & Fernando Py \\
\hline Charles Swann & Charles Swann & Charles Swann \\
\hline Mme de Saint-Loup & Sra. Saint-Loup & Mme de Saint-Loup \\
\hline Mme de Villeparisis & Sra. de Villeparisis & Sra. de Villeparisis \\
\hline Flora & Flora & Flora \\
\hline Mme Materna & Sra. Materna & Sra. Materna \\
\hline Françoise & Françoise & Françoise \\
\hline Mme Verdurin & Sra Verdurin & Sra Verdurin \\
\hline Odette de Crécy & Odette de Crécy & Odette de Crécy \\
\hline Docteur Cottard & Dr. Cottard & Dr. Cottard \\
\hline Gilberte & Gilberte & Gilberte \\
\hline Léonie & Léonie & Léonie \\
\hline Octave & Octave & Octave \\
\hline Mme Goupil & Sra. Goupil & Sra. Goupil \\
\hline M. Legrandin & Sr. Legrandin & Sr. Legrandin \\
\hline
\end{tabular}

O mesmo não podemos observar em relação às personagens históricas, caso em que a maioria foi traduzida, tanto por Mário Quintana, quanto por Fernando Py, como mostra o quadro seguinte.

\begin{tabular}{|c|c|c|}
\hline \multicolumn{3}{|c|}{ Personagens históricas e culturais } \\
\hline Original & Mário Quintana & Fernando Py \\
\hline François 1er & Francisco I & Francisco I \\
\hline Charles Quint & Carlos V & Carlos V \\
\hline Charles VI & Carlos VI & Carlos VI \\
\hline Ève & Eva & Eva \\
\hline Adam & Adão & Adão \\
\hline Louis XVI & Luís XVI & Luís XVI \\
\hline Geneviève de Brabant & Geneviève de Brabant & Geneviève de Brabant \\
\hline
\end{tabular}


2. The practice, didactics and critiques of translation / Pratique, didactique et critique de la traduction / Praxis und Didaktik des Übersetzens, Übersetzungskritik / Pratica, didattica e critica della traduzione / Práctica, didáctica y crítica de la traducción/

Como podemos observar no quadro abaixo, a maioria dos nomes de municípios, cidades e países foi mantida como no original pelos dois tradutores, excetuando-se os nomes já traduzidos e consagrados na língua portuguesa (Veneza para Venise; Florença para Florence). Alguns nomes de lugares e monumentos foram traduzidos pelos dois tradutores, como, por exemplo, Cathédrale Sainte-Marie-des-Fleurs (que ficou Catedral Santa Maria das Flores). Já outros permaneceram como no original nas duas traduções, como é o caso de faubourg Saint-Germain (nas traduções, bairro de Saint-Germain) e de Cathédrale de Chartres (nas traduções, catedral de Chartres). A famosa avenida de Paris, Les Champs-Elysées, foi traduzida por Mário Quintana para Campos Elísios, fato que não observamos na tradução de Fernando Py, que manteve o nome como no original. Outra diferença observada entre as duas traduções foi nos nomes de algumas ruas e bairros. Constatamos que Mário Quintana traduziu a maioria dos nomes de ruas e bairros, principalmente aqueles que levam nomes de santos, enquanto Fernando Py deixou a maioria como no original, sem traduzi-los.

\begin{tabular}{|c|c|c|}
\hline \multicolumn{3}{|c|}{ Topônimos } \\
\hline Original & Mário Quintana & Fernando Py \\
\hline Combray & Combray & Combray \\
\hline Guermantes & Guermantes & Guermantes \\
\hline Tansoville & Tansoville & Tansoville \\
\hline Balbec & Balbec & Balbec \\
\hline Paris & Paris & Paris \\
\hline Doncières & Doncières & Doncières \\
\hline faubourg Saint-Germain & bairro de Saint-Germain & bairro de Saint- \\
& & Germain \\
\hline Cathédrale de Chartres & Catedral de Chartres & Catedral de Chartres \\
\hline Vésuve & Vesúvio & Vesúvio \\
\hline Bayeux & Bayeux & Bayeux \\
\hline Coutances & Coutances & Coutances \\
\hline Vitré & Vitré & Vitré \\
\hline Questambert & Questambert & Questambert \\
\hline Pontorson & Pontorson & Pontorson \\
\hline Lannion & Lannion & Lannion \\
\hline
\end{tabular}




\begin{tabular}{|c|c|c|}
\hline Lamballe & Lamballe & Lamballe \\
\hline Benodet & Benodet & Benodet \\
\hline Pont-Aven & Pont-Aven & Pont-Aven \\
\hline Quimperlé & Quimperlé & Quimperlé \\
\hline Rue Saint-Hilaire & Rua de Santo Hilário & Rua Saint-Hilaire \\
\hline Rue Saint-Jacques & Rua de São Tiago & Rua Saint-Jacques \\
\hline $\begin{array}{l}\text { Rue Sainte } \\
\text { Hildegarde }\end{array}$ & $\begin{array}{l}\text { Rua de Santa } \\
\text { Hildegarda }\end{array}$ & Rua Sainte Hildegarde \\
\hline Rue du Saint-Esprit & Rua do Espírito Santo & Rua do Saint-Esprit \\
\hline Rue de l'Oiseau & Rua do Pássaro & Rua de l'Oiseau \\
\hline Grand-Pré & Prado Grande & Grand-Pré \\
\hline Petit-Pré & Prado Pequeno & Petit-Pré \\
\hline Champs-Elysées & Campos Elísios & Champs-Elysées \\
\hline $\begin{array}{c}\text { Cathédrale Sainte-Marie- } \\
\text { des-Fleurs }\end{array}$ & $\begin{array}{c}\text { Catedral Santa Maria } \\
\text { das Flores }\end{array}$ & $\begin{array}{c}\text { Catedral Santa Maria } \\
\text { das Flores }\end{array}$ \\
\hline Venise & Veneza & Veneza \\
\hline Florence & Florença & Florença \\
\hline Toscane & Toscana & Toscana \\
\hline Normandie & Normandia & Normandia \\
\hline
\end{tabular}

Observamos, portanto, que Mário Quintana e Fernando Py optaram pela não tradução de uma parte considerável dos nomes próprios do original. Entendendo-se que Proust dedica uma parte importante de sua obra à escolha dos nomes de sua narrativa, podemos dizer que os tradutores, na verdade, mantiveram as conexões simbólicas que fazem parte do universo literário de Proust, construído por meio de idealizações e experiências reais que não podem ser dissociadas de seu todo.

Para Ballard (1998), a não tradução de nomes próprios aproxima-se do processo de empréstimo em relação a termos da língua de partida que não existem na língua de chegada. Esse aspecto pode aclarar a escolha dos tradutores em traduzir nomes já consagrados na língua portuguesa (como Veneza e Florença) ou nomes que, traduzidos, aproximam o leitor da narrativa e do original (como catedral Santa Maria das Flores). Nesses casos, os nomes são signos, por vezes, desprovidos de associações importantes para compreendermos a narrativa. $\mathrm{O}$ mesmo não podemos afirmar em relação à escolha de não traduzir alguns nomes (signos 
2. The practice, didactics and critiques of translation / Pratique, didactique et critique de la traduction / Praxis und Didaktik des Übersetzens, Übersetzungskritik / Pratica, didattica e critica della traduzione / Práctica, didáctica y crítica de la traducción/

revestidos de lembranças, memória, cultura), pois mais do que empréstimos por falta de correlação entre as duas línguas, observamos uma falta de correlação entre o universo proustiano e qualquer outro universo que tentemos descrever. Nesse caso, os tradutores optaram por uma transferência dos nomes, pois estes são carregados de simbologia e de significados que transmitem a busca do autor por uma verdade que se desenvolve por meio da aprendizagem dos signos. Apesar de a transferência dos nomes do original para as traduções ser um traço presente nos textos dos dois tradutores, ele é ainda mais marcante na tradução de Fernando Py (2004), a mais recente, em que encontramos pouquíssimos nomes próprios traduzidos.

\section{Considerações finais}

Este trabalho teve por objetivo apresentar, ainda que sucintamente, o tratamento dado à tradução dos nomes próprios pelos escritores/tradutores da Editora e Livraria do Globo de Porto Alegre. Na comparação das traduções realizadas por eles com retraduções mais recentes, vimos que a tendência geral era de uma maior interferência no texto do original.

Podemos chegar por meio das análises às seguintes considerações:

- Os tradutores da editora do Globo tendem a traduzir mais os nomes próprios dos personagens ficcionais e a adaptar a grafia foneticamente de modo a trazer o texto para mais perto do leitor da língua de chegada;

- Os tradutores contemporâneos tendem a não traduzir, usando os nomes próprios como empréstimos, o que pode indicar uma tendência a respeitar mais a cultura de partida;

- Em ambos os casos, vemos que os tradutores tendem a traduzir referentes culturais e históricos que fazem parte da cultura geral do contexto de chegada, como nomes de lugares e de monumentos;

- A tendência mais contemporânea a não tradução de nomes de lugares e de personalidades históricas aponta para a disseminação da cultura, sobretudo ocidental, facilitada pela internet;

- Há uma certa hesitação na tradução de hipocorísticos: Drummond faz uma adaptação de Mouche enquanto Verissimo mantém Face e Mug;

- Há, de modo geral, uma certa liberdade na tradução dos títulos das obras; 
- No caso do título brasileiro Felicidade, a retradução mantém o título dado por Veríssimo, apesar de constatar que não é o mais adequado.

\section{Referências Bibliográficas}

Ballard, Michel. «La traduction du nom propre comme négociation». Palimpsestes 11 (1998) : 199-223. " Traduire la Culture »

Balzac, Honoré de. Les paysans. Bruges : Bibliothèque de la Pléiade, 1955.

Balzac, Honoré de. "Os camponeses ». Tradução de Carlos Drummond de Andrade. In A Comédia Humana. Porto Alegre: Globo, 1954.

Berman, Antoine. A prova do estrangeiro: cultura e tradução na Alemanha romântica. Tradução de Maria Emília Pereira Chanut. Bauru: EDUSC, 2002.

Berman, Antoine. Pour une critique des traductions: John Donne. Paris: Gallimard, 1995.

Candido, Antonio. Formação da Literatura Brasileira: momentos decisivos. 6 ed. Belo Horizonte: Itatiaia, 2000 [1958].

Costa, Walter. Um tradutor invisível. Poesia sempre 10. 16 (outubro de 2002): out02.

Esqueda, Marileide Dias. $O$ tradutor Paulo Rónai: o desejo da tradução e do traduzir. Campinas: Unicamp, tese de doutorado, 2004.

Even-Zohar, Itamar. "La posición de la literatura traducida en el polisistema literario ». Tradução de Montserrat Iglesias Santos, revisada pelo autor. In : Itamar Even-Zohar. Teoría de los Polisistemas, Estudio introductorio, compilación de textos y bibliografia por Montserrat Iglesias Santos. [Bibliotheca Philologica, Serie Lecturas] Madrid: Arco, 1999: 223-231.

Gonçalves, Letícia. A reescritura de Katherine Mansfield por Erico Verissimo: análise descritiva da tradução para o português de Bliss \& other stories. [En ligne] Disponível em: http://www.athena.biblioteca.unesp.br/exlibris/bd/bas/33004048019P1/2008/ goncalves_ls_me_assis.pdf. (Acesso em 20 mai. 2011).

Lefevere, André. Tradução, reescrita e manipulação da fama literária. Bauru: EDUSC, 2007.

Mansfield, Katherine. Felicidade. Tradução de Érico Veríssimo. Rio de Janeiro: Nova Fronteira (Coleção Universo), s/d: 193.

Mansfield, Katherine. Felicidade. Tradução de Érico Veríssimo. Porto Alegre: Livraria do Globo (Coleção Nobel), 1940: 285.

Mansfield, Katherine. Felicidade e outros contos. Tradução de Julieta Cupertino. Rio de Janeiro: Revan, 2000: 140.

Mansfield, Katherine. The short stories of Katherine Mansfield. New York: Alfred a Knopf, 1965: 688.

Martinet, H. Les noms propres dans la traduction littéraire. Meta 27. 4 (1982): 392-400.

Milton, John. O Clube do Livro e a Tradução. Bauru: Editora da Universidade do Sagrado Coração, 2002.

Proust, Marcel. Du côté de chez Swann. Collection folio Classique. Paris: Gallimard, 1987. 
2. The practice, didactics and critiques of translation / Pratique, didactique et critique de la traduction / Praxis und Didaktik des Übersetzens, Übersetzungskritik / Pratica, didattica e critica della traduzione / Práctica, didáctica y crítica de la traducción/

Proust, Marcel. No caminho de Swann. Tradução de Mário Quintana. Editora Globo, 1948.

Proust, Marcel. No caminho de Swann. Tradução de Fernando Py. Editora Ediouro, 2004.

Risterucci-Roudnicki, Danielle. Introduction à l'analyse des œuvres traduites. Paris: Armand Collin, 2008.

Rónai, Paulo. Balzac e a Comédia Humana. Porto Alegre: Globo, 1947.

Rónai, Paulo. Escola de tradutores. Rio de Janeiro: Nova Fronteira, 1987 [1952].

Sousa, Germana. "O Brasil em Oran: tradução de La peste, de Camus, por Graciliano Ramos ». In: Germana H. P. de Sousa, Ana Laura Reis Correa, Deane Maria Fonseca Castro e Costa (org.): Literatura e História: Questões dialéticas em nação periférica. Brasília: CEEL/Grupo de pesquisa Literatura e Modernidade Periférica - CnPq/TEL/UnB, 2009.

Strathen, Paul. Virginia Woolf em 90 minutos. Rio de Janeiro: Jorge Zahar Editor Ltda., 2009.

Toury, Gideon. Descriptive Translation Studies and Beyond. Amsterdam-Philadelphia: John Benjamins, 1995: 53-69. Disponível em: http://www.tau.ac.il/ toury/works/GTRole-Norms.htm. (Acesso em 25 maio 2011).

Woolf, Virginia. Orlando - A biography. London: Penguin Books, 2000.

Woolf, Virginia. Orlando. São Paulo: Círculo do Livro, s/d. 